\title{
A LANGUAGE FROM BURU: WAYAPO-INDONESIAN WORDLIST
}

Hersri

Edited by John U. Wolff

\section{Author's Foreword}

The data assembled here represent the results of "labor-on-the-side" carried on over the nine years, 1969-78, during which I resided in the Wayapo valley. How much knowledge would have been obtained and how great its scientific value would have been had those nine years been devoted to continuous academic study!

It may well be that my residence in the lowlands of the Wayapo valley was a blessing in disguise. Along with tens of thousands of other souls, I came to live as a new inhabitant of that valley, not to carry out any theoretical, scientific endeavor, but rather to carry on practical, useful labor. Not for brain-work, but for brawn-work. Our task was to change the face of Buru--with its swamps, its jungles, and its scrub savannahs--by turning it into a region of ordered kampung surrounded by hectare upon hectare of sawah and ladang.

Naturally enough, not a single one among those tens of thousands of new arrivals came with the equipment necessary for a scientist. Not one of us had even a sheet of paper or a pencil, let alone a single reference book. Thus my data on the Wayapo language were collected with the aim of presenting them to the forum of linguistic science without the support of any academic literature. The one and prime support I had--which proved, however, strong enough to give birth to this text-was the will and determination to undertake the task and bring it to a conclusion. That was my point of departure, and subsequently that too animated the one ultimate resource on which I had to depend--the human memory, with all its limitations.

It was fortunate that in our tens of thousands we "represented" various social strata, various levels of intelligence and education, and originated from various corners of the motherland. Thus my companions formed a reference library for testing my memory and my interpretations. And it was they who functioned as dictionaries of regional languages that I had frequently to open and read for comparative material.

There were, of course, references to this Buru language in the printed linguistics lecture notes that I read many years ago. But they were passing references that did not even fill one page, as though the language was completely insignificant from a linguistic point of view; and I myself was never in the slightest bit "enthralled" by the vocabulary of Buru. But then history wrote its own pages and "enthralled" millions of people in the world with this one word: Buru. And dragged off tens of thousands of people to take up residence for many years on that island. There I discovered linguistic phenomena that indeed should not be passed over.

After making comparisons with other regional languages, I noticed various things that seemed to require further investigation. The Wayapo language clearly formed a link in the evolutionary chain of languages in Indonesia. For that reason 
it is not impossible that languages like those of Buru can be used to test various existing hypotheses, and particularly to test linguistic theories about the Indonesian language.

Attracted initially by the way of life of the Wayapo society in the kampung of Kamihalahin, I began to collect data about it, and in particular about its adatistiadat. For I believed that this adat-istiadat formed the background for the linguistic problems that I proposed to treat. I took advantage of every opportunity to meet and talk with its members, from various different kampung; day by day, and year by year; from the time when they barely understood one or two words of bahasa Indonesia (1969) to the time when they had mastered it reasonably and could use it fluently as a communications bridge with the thousands of newcomers dropped down in the valley bequeathed them by their ancestors.

The adherents of the language of the plain of the Wayapo valley form part of the Alfuru suku, who inhabit the interior of Buru. They are scattered about in hamlets all over the valley floor and also in the foothills by the river's headwaters. It is for this reason that I call their language, as I have recorded it, the Wayapo language. They themselves call the language they use Lien Liak, which literally means "speaking language" with the connotation "local language."

The Wayapo river has formed a heart and arteries giving life to the inhabitants for who knows how many ages past. Down it came cajeput oil and sago starch/flour which, via the harbor of Ambon, flowed out to the wider world and made the island of Buru known to mankind. Thus I adopt the name "Wayapo language" for good social and historical reasons. In fact the Wayapo language only forms a dialect, albeit a dominant one, in the area along and around the river valley. Other dialects can be found in the hilly zones that form the valley's walls; in the south of the island; along the north coast; and in the Sula region. Specifically with regard to the two last-mentioned dialects, they form a fusion between the Wayapo language and other languages from outside the island.

The area in which Wayapo speakers live covers about 250 square kilometers, and about 4,000 souls. Up to the end of the 1960s the region was still essentially "closed." Contact with the "outside world" was virtually unknown. The native speakers of Wayapo still held firmly to an animism that they call "pamali." Islam and Christianity, let alone Hindu-Buddhism, etc., were still far too weak to be termed at all influential there.

In view of its isolation, I am persuaded that the Wayapo language is still relatively uncontaminated by the influence of other languages. And this "purity" makes it easier to trace its genetic path. For certain, the Wayapo language of the valley of the Wayapo is still quite "pure" by comparison with the coastal dialects, which have been influenced both by other languages in the Indonesian family, and by languages accompanying social, economic, and political developments.

Aside from Kamihalahin, I also visited the kampung of Koramaslahin, Baman, Utaramalahin, Itilahin, Fumiei, Kalamolahin, Waisukan, Waigaba, Wailo Besar, Wailo Kecil, Wailonangan, Waigrenengan, Waigeren, Simlo, Wailata, Parabulu, Waidi, Waidilele, Wailodaka, Manakota, Waimiten, Kisitoho, Waibloi, Kubalahin, and Walgan: some of them small kampung consisting of two houses, some much larger with ten or more houses. Among them were kampung which have now disappeared and become jungle once more; others vanished when flooded by the changing course of the Wayapo river; still others made way for the sawah and ladang of the newcomers, who outnumbered them by four to one. As examples I can give: the kampung of 
Kamilalahin, abandoned in November 1969 because of inter-kampung fighting; Simlo and Manakota, which were turned into sawah in 1971 and 1972 ; Kalamolahin which was swept away by floods in 1969; and Wailonangan of which only three houses remained in 1978--the rest had been washed away by the Walapo river in full spate.

Meetings with the local people also resulted from the need to exchange articles of consumption--either in the jungle or in places previously agreed on for berbaku pele (barter). They also occurred on playing fields and in the yards of the art centers of our Units, if we were playing sports and/or presenting shows. And when the rice harvest was ready, they would come into our rice fields from all directions to glean the rice seeds scattered about in the fields.

It was through encounters of these kinds that I carried on my linguistic "research." Without any intention of using their language actively, I studied it and now "record" it in this text before it becomes extinct. If Sanskrit and Old Javanese, with their large vocabularies and elaborate grammar, could die; if New Javanese, which is scarcely less rich, can be marginalized by the development of society, then it is impossible that the Wayapo language, which from the linguistic point of view is still very simple, will be able to survive. Only, perhaps, if the area remained "closed," as it was before the 1970s (the years when the political prisoners arrived and took up residence), would Wayapo be able to live on for another few generations. And in the meantime, if this closedness were accompanied by an appropriate execution of provincial government policy in accordance with the 1945 Constitution both in letter and in spirit (see The Preamble, Articles 18, 32, and 36 with their official explications), there would be no reason to fear that regional languages and orthographies would disappear; and indeed there is no good reason why this should happen. For, naturally, it is inhuman, and not in keeping with Pancasila and the Constitution, if, for the sake of preserving regional cultures, they are treated as "living museums," i.e., maintained in continuing isolation from development.

The essence of the national ideal is sufficiently clearly expressed in the formula bhinneka tunggal ika. The beauty of a composition depends precisely on the perfected development of each element contained with it. The ethnic and cultural unity (persatuan) of the nation must be achieved, but the unification (kesatuan) of the nation is a political and administrative strategy.

The fate that the Wayapo language has experienced has perhaps already been, is being, or will be experienced by other regional languages. Huge, unceasing waves of the most modern civilization and culture inundate the young shoots of local civilizations and cultures, directly via new residents whose numbers frequently are far greater than those of the original inhabitants, and indirectly via the products of technological development. This has happened too in the Wayapo valley. The old full monopoly of the Wayapo language over the entire population--as the laws of Raja Kayeli ordained--has lost its power. Social structure and way of life too have been changing rapidly and fundamentally, leaping over decades of evolutionary development in a process of Umwertung aller Werten--and for good.

The "life" of their language will not be able to escape this process. I see the likelihood, within the framework of these sikon [situations and conditions], that the Wayapo language will become extinct, slowly or rapidiy, as a result of all these tendencies. The present text has been prepared for this reason. If the language's death is unavoidable, at least let some memorial be left behind, like a link in the beautifully variegated necklace of a single national linguistic history. What a pity that one or two pearls have had to drop off this necklace and be buried in the dust of our motherland's history. May what dies at least contribute to the fertility of the nation.... 


\section{Editorial Note}

The manuscript which Hersri compiled contains grammatical notes, historical comments, Indonesian-Buru and Buru-Indonesian word lists, and sample sentences. It is possible to publish only the Buru-Indonesian word list, but all of the forms which are given in the word lists are presented here. There are said to be four closely related dialects on Buru, of which one, the dialect of Masarete (Southwestern Buru), has been described in some detail. ${ }^{1}$ The material here shows similarities with the Masarete dialect, but only a minority of the forms in this list coincide with or resemble forms published in the Masarete materials. The language is Austronesian and shows resemblances to other Austronesian languages spoken in the neighborhood.

We print the forms exactly as they were written in the manuscript, except that breaks between word boundaries are marked, and the listing is strictly in alphabetical order. Many of the entries clearly contain prefixes or are phrases.

We list these both under the root and again with the prefix or the words which precede it. It is not certain how accurately the vowels are transcribed. The dialect of Masarete is described as having ten vowels; our manuscript is written with only five vowels, and there is internal evidence that at least the symbol " $e$ " refers to a central vowel (pepet) in some forms and a front vowel in others. Further, there is inconsistency in that the same forms are transcribed with " $u$ " in one place and with "o" elsewhere, and there is a similar alternation between " $i$ " and "e." Whether these alternations represent variations in pronunciation or are due to varying perceptions on the part of the compiler is difficult to determine. In any case, we print all the various transcriptions that are given in the manuscript. Similarly, glottal stops are marked with an apostrophe, but not consistently so. There are probably many more glottal stops than appear in this manuscript, and possible some of the forms written with final "-k" have glottal stop not "k." Again we give all variations which appear in the material. Other variations of forms which appear in the materials reflect for the most part morphological processes. In a few cases we had reason to believe that a variant transcription arose from mistakes in copying. In these instances we listed all variants, marking the forms found outside of the Buru-Indonesian list with a preceding question mark.

The Buru (Wayapo) word is underlined and appears first in the list, followed by the Indonesian and then the English equivalents.

1. H. Hendriks, Het Burusch van Masarete, Koninklijk Instituut voor de Taal-, Land-, en Volkenkunde van Nederlandsch-Indië (The Hague: Nijhoff, 1897). 


\section{WAYAPO-INDONESIAN / ENGLISH WORDLIST}

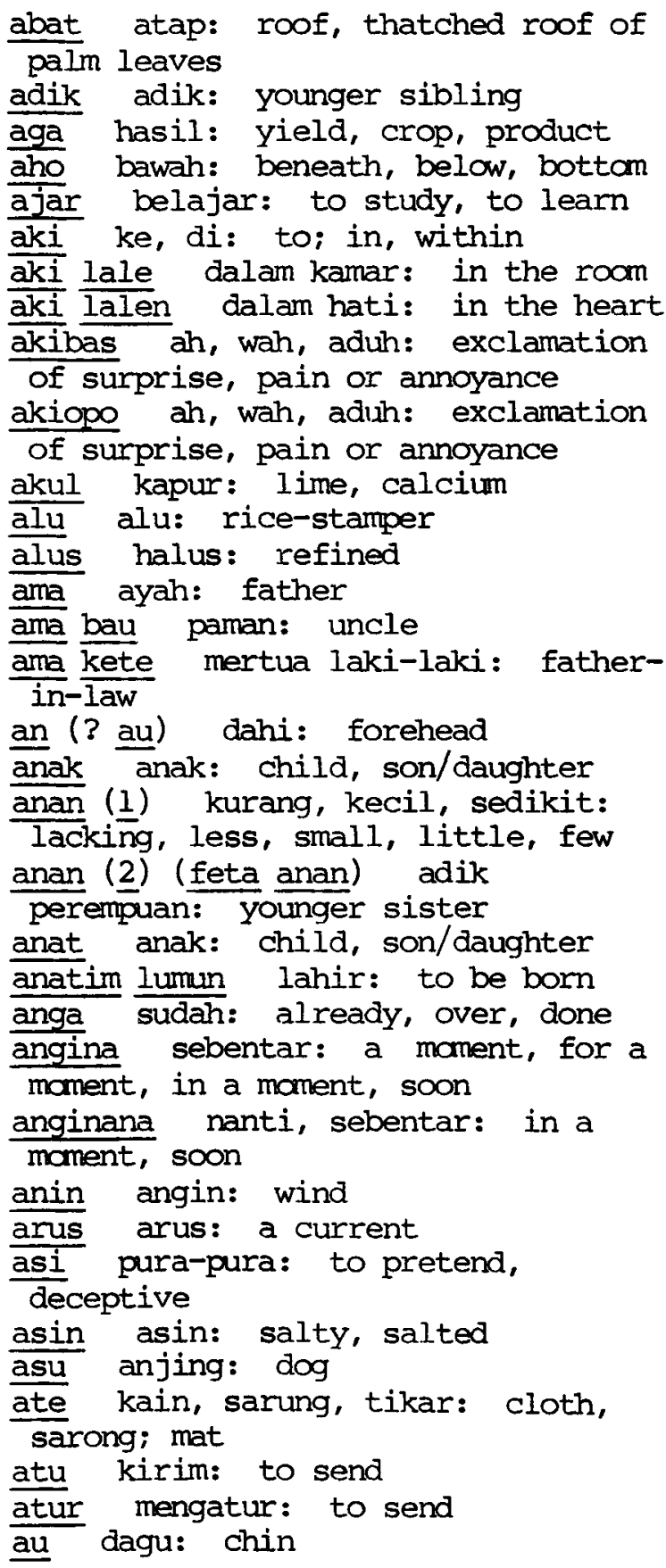

awan pinggang: waist baban pinggir: edge, border bablaba (? baplaba) ketimun: cucumber

bado mana: where, of what kind bage membagi: to divide, to share bagut (1) besar: large

bagut $(\overline{2})$ (wai bagut) rawa, danau: swamp, marsh; lake

bahai biarlah: never mind

bahan alat: tool, instrument

baho buruk: bad, rotten; worn out baho (dabaho) (? daboho) berbau, basi: to smell of: rotten, spoiled bajinga gagah, bagus: strong and handsome, good-looking baka pecah membuka: to break; broken, shattered; to open bakungain abu: ash bala' dosa, sial, bahaya: sin; misfortune; calamity; danger balaba mentimun: cucumber bali kiri: left, left-hand baman nama suku 'bama': name of the 'Bama' ethnic group

bana (1) di sini: here, in this place

bana (2) baru: new, recent

bana (3) api: fire

bana elen abu api: ashes of a fire bana fene asap api: smoke of a

fire

banar-banar benar-benar: truly, really, seriously

bangit keringat: sweat

bangkali barangkali: perhaps, maybe

bango bangun: to wake, to get up bani di sini: here, in this place bantu bantu: to help

? baplaba mentimun: cucumber bara jangan: negative imperative - don't barani berani: dare, daring, brave 
bargili (dabargili) miring: at an angle, aslant, askew; to slant bar midi' (? bar midi) gelap: dark, obscure

basa (1) (dabasa) basah: wet, damp basa (2) (dabasa) pedas: spicy-hot

base (1) kipas: fan

base $(2)$ kapas: cotton wool

basi lolos: to slip off, to

escape, to came free

baso (1) kalau: if, when

baso $(\overline{2})$ dari: from, of, out of

bata (I) tempel: to stick to, to achere to

bata (2) (dabata) meletakkan: to

put, to place, to lay s.t. down

bau (ama bau) paman: uncle

beben (raman beben) alis: eyebrow

beha (dabeha ) beban, berat, kuat:

burden; heavy; strong

behat berat: heavy

bela (menyao bela) bertanggung

jawab: to be responsible; to

account to/for

bendera bendera: flag

bera buka: open

berang merah: red

beta kena: to be struck; to be subject to; to undergo

betahe lenjap: gone, vanished

beto (1) betul: correct, true

beto $(\underline{2})$ malam hari: night, nighttime

beto-beto malam-malam: late at night

beya rindu, (? randu): longing,

homesickness; to yearn for; (? kapok)

biak sagu: sago

biasa biasa: usual, customary; ordinary, common, to be used to s.t. biglifut belahan: split, splinter, crack

bija pohon randu: kapok-tree

bilis iblis: devil, Satan

bina bilang, omong: to speak, to say, to talk

binatang binatang: animal

binci benci: to hate

birik buang: to throw, to throw away

biru biru: blue

bisi belah: to split, to splinter, to halve biya (1) harus: to have to, must

biya $(\underline{2})$ randu: kapok

bobo berak: to defecate

bodi tumbang: to crash down, to

tumble down

boho (daboho) bohong: lie,

falsehood; to lie

boho' (raman boho') buta: blind

boko bongkok: humped, crooked,

bent over, stooping

boko (daboko) membongkok: to

stoop, to bow down

bole boleh: to be permitted; may

bolo' (mana bolo', geba bolo')

bujang: unmarried, bachelor

bolok bujang: unmarried, bachelor

boti (uta boti) jamur meranti:

type of edible fungus

boti-boti semua: all, every

broko mencari: to seek, to look

for

bruah pripean (javanese): in-laws

buaya buaya: crocodile

bubu kakek: grandfather; old man

buete peti: case, chest, crate

buhut jahat: wicked, evil

bui timang: to cradle, to lull

bui-bui ayunan anak timang:

cradle; rocking of a cradle

bukakabot tanah: land; soil

bukbilah gambar: picture, drawing, illustration

bukit bukit: hill, mountain

bukut jahat: wicked, evil

bunga bunga: flower, blossom

bunin bubungan: ridgepole, rooftop

burung burung: bird

busafa maaf: forgiveness, pardon

butun-butun kadang-kadang:

sometimes, occasionally

cami berpakaian, memakai: to wear

(clothes), to be dressed, to dress

in

cangkir cangkir: cup

cara bicara: to speak, to talk

cara terang terus terang: frank,

open, direct

cele hampir: almost, nearly

cia sembilan: nine

coba mencoba: to try, to attempt;

to test

cohi memburu: to hunt

coko mencari, memburu: to seek; to

chase 
conto contoh: example, sample

da dia: he, she

dabaho berbau: to smell of

dabargili miring: aslant, askew,

at an angle

dabasa basah: wet, damp

dabasa pedas: spicy-hot

dabata meletakkan: to place, to

put, to lay s.t. down

dabeha beban, berat, kuat: burden;

heavy, onerous; powerful; strong

dabgaoli hamil: pregnant

daboho bohong: lie, falsehood

daboko membongkok: to stoop, to

bow down

daci tusuk: pin; skewer

dadaleka lengkung, bengkok: curve, arc; curved

dadaleko bengkok: curved, crooked

dadao mentah: raw, uncooked

dade akar: root

dadeak berhenti: to cease, to stop

dademe lurus, kaku: straight;

stiff; awkward

dadiso terbit: to arise; to

appear; to emerge

dadofu lebih: more, greater than

dae darat: land, shore

daego mengambil, membawa: to take,

to fetch; to bring, to carry

dafango bangun: to wake; to rise;

to get up

dafato terbang: to fly

dafila petir: thunderclap

dafogi membasahi: to dampen

dafru' menyala: to flame

dagala tersangkut: to get caught

on; to get involved

dagida mega, awan: cloud

dagiha telentang: to lie on one's

back

daglina jernih: clear; pure

dagogo halilintar: flash of

lightning; thunderbolt

dagolo' petir: thunderclap

dagosa baik, cantik, kuat, gagah:

good; beautiful, lovely; strong;

brave, handsome

dahaka ikal, keriting: curly,

wavy; crinkly

dahoni masak: to cook

dahor $i$ condong: to tend to, to

incline; leaning, inclining

dai ke, di: to, towards; in daiga minta: to ask, to request

daigu manja: spoiled (of a child)

daiso bergerak: to move, to be in

motion

dakabi tebal: thick, dense

dakasi datefa cukil: to dig out;

to gouge out; to pick

dakeda tua: old

dakene tuli: deaf

dakita datang: to come, to arrive

dakita fulan datang bulan:

menstruate

daklekotuhun jalan belok: curving

road, a curve in the road

dakoke merangkak: to crawl on

hands and knees; to grovel

dakrei tak bisa: cannot, be unable

to

dakri takut: to be afraid

dalahi sampai: to reach, to

attain; up to, until

daleawarot muat: to contain, to

hold

daleka (dadaleka) lengkung,

bengkok: curved, bent; crooked

daleko bengkok: bent, crooked

dalibo keruh: turbid, muddy;

disturbed

daloli tergelincir: to slip

dalu sirih: betel

dalubuk bermaksud: to intend, to mean, to have the intention to

damako jinak: tame; gentle

damao berteriak: to shout, yell, scream

damata mati: dead

damedet hitam: black

damei sesak, seret: sluggish,

tight; blocked; suffocating

damgea malu-malu: shy, bashful,

coy

damhama ringan: light in weight, easy

damidi gelap: dark, obscure

damifi tipis: thin, scarce

damili sungguh-sungguh:

earnest $\left(l_{y}\right)$, sincere (ly),

wholehearted (ly)

daminat (1) teduh: calm, unruffled

daminat $(\overline{2})$ terang: clear, bright

damisa manis: sweet

damiti bersih: clean

damito kecut: sour; shrivelled, shrunken 
darkele tinggi: high; tall

damkoani bagaimana: how, by what

means

damolo tenggelam: to sink, to have sunk; to drown

dampait pahit: bitter

damuti sakit: sick, ill; sore,

painful

danewe hidup: alive, life

dangodon berkelahi, adu: to fight

with fists; to quarrel; to pit s.o.

or s.t. against another

danika bertanya: to ask a question

dao (dadao) mentah: raw, uncooked

dao-dao diam-diam: quietly;

secretly

daok kakek, nenek: grandfather;

old man; grandmother; old woman

daoto ada: to be, to exist

dapao taruh di bawah: to place

underneath; to put down on the floor

dapara rendah: low; short; humble

dapaso pecah: to be broken to

pieces; to be smashed

dapato panas: hot; heat

dapedet busuk: rotten, putrid

dapei sakit: sick, ill; sore, painful

dapepe menekan: to press

dapesa menetaskan: to hatch

(eggs); to produce, to cause to

happen

dapodi kenyang: full (of appetite), satiated

daptea berdiri: to stand, to exist

daptea demdemi berdiri tegak: to

stand up straight

daptuak mencuri: to steal

daptuha ludah: spittle

daput tenggelam: to sink, to have

sunk; to drown

dara (wai dara) air pasang:

incoming tide

daraki kotor: dirty

darekeng menganggap, menghitung:

to regard, to consider; to

calculate, to count

dareru menelan: to swallow

dasafe membeli: to buy

dasida panas: hot; heat

daskabi tebal: thick, dense

daskena rindu: yearning, longing,

homesickness; to yearn for

dasmirat (1) licin: smooth; slippery

dasmirat (2) kain: cloth; clothing datamo sial: unlucky, doomed datanggufa telungkup: face down, to lie face down

datare tebang: to fell trees

datefa (dakasi datefa) cukil: to

gouge out; to pick

datekel hinggap: to perch

datifo terbang: to fly

datonga menaruh di atas: to place

on top of s.t.

datote lemah, lunak: weak; soft,

unresisting

datura mematuk: to peck; to bite

dau membunuh: to kill

dauna penuh: full (of s.t.)

daut lelah: tired, exhausted

dawa siang: daytime; forenoon

dawa-dawa siang-siang: when it is

daytime

dawai basah: wet, damp

dawana hari ini: today, this day

dawangi kering: dry

dawao bergerak: to move, to be in motion

deak (dadeak) berhenti: to cease, to stop doing s.t.; to come to a stop

defo duduk, tinggal: to sit; to reside

degen menumbuk: to pound, to

crush; to strike; to crash into s.t. dela putus: broken off, severed

demdemi tegak: erect, upright deme (dademe) lurus, kaku: straight, direct; stiff; awkward

dena pohon waru: k.o. tree

dere (1) teduh: calm, unruffled

dere () terang: clear, bright

diak singgah, berhenti: to stop

by, to stop in for a visit; to

cease, to stop doing s.t.

dika lain: other; different;

remaining

dikat lain: other; different;

remaining

disi hilang: vanished, gone; to be

lost

diso (dadiso) terbit: to rise; to

emerge

do mana: which; where

do (kafi do, fi do) dari mana:

where from 
dodi ubi: k.o. yam

dofu (dadofu) lebih: more, greater

than; extra

doi bodoh, dungu: stupid,

unintelligent

dola memiting: to hold onto s.t.

dole katak: toad, frog

dolingisin ampong: toothless; gaptoothed

donot lolos: to slip off; to

escape

duen rakit: raft

dufa mendapat, jumpa, mencapai: to

encounter; to attain; to achieve

duhutniwe punggung: back (anat.)

dulan tumbuh: to grow; to develop

dulen menggonggong: to bark

ega membara: to be aglow

ego (daego) mengambil, membawa: to

take, to fetch; to carry

eha tuak: toddy, palm-wine

ehe ya: yes

elen abu: ash

elen (bana elen) abu api: ashes of

a fire

elet balai-balai: couch, bamboo

cot

elete tempat tidur: bed

emda saudara sepupu: cousin

emsili (? msili) bersih: clean

ere keriting: curly, wavy; crinkly

esa (1) menyeret: to drag along

esa ()ㅡ menggoyang: to shake, to

rock

eta jadi, biar, maka jadi:

finished, done; to be, to serve as;

never mind; and so it happened

that...

etak beberapa: some, several

ewang hutan: jumgle, forest

fafa nyunggi: to carry on the head

fafan bangku, papan: bench; board

fafu babi: pig, boar

fage menombak: to stab with a

spear

fahan tangan: hand

fahanan fuan pantat: buttocks

faka (1) bangun: to awake; to

rise; to get up

faka (2) tarik: to tug; to pull at

s.t.

faki seberang: across; opposite

fako tembakao: tobacco

fale angkat: to lift up faleke adik perempuan: younger sister

fango (dafango) bangun: to awake;

to rise; to get up

fangu bangun: to awake; to rise;

to get up

faon bau: odor, smell

fargele tumpah: to spill

fasa terbang: to fly

fastela memotong: to cut, to sever

fatak tukar: to exchange

fatan (1) tukar: to exchange

fatan (ㅁ) gemuk: fat, stout;

grease

fatehe bersin: to sneeze

fato (dafato) terbang: to $f l y$

fatu batu: stone, rock

fatu nado batu asah: whetstone

fau bau: odor, smell

fe lagi, juga, lalu, atau: again;

as well as, further, also; or

feda membuka: to open

fefan lubang: hole

fehe mengayuh, dayung: to row, to paddle

fehut muda, baru: young; new

fei sakit: sick, ill; sore,

painful

fena pantai: shore

fene asap: smoke

fene (bana fene) asap api: smoke

of a fire

fenga lalat: fly (the insect)

feni dulu: previous, former;

previously; beforehand

fenikul sikut: elbow

fesan bahu: shoulder

feta kakak perempuan: elder sister

feta anan adik perempuan: younger sister

feten mendung: cloudy, overcast

fido dari mana: where from

fifa (gegenan fifa) ketiak: armpit

fifin bibir, pipi: lip; cheek

fila (1) berapa: how much, how many

fila (2) (dafila) petir:

thunderclap

fili dari: from, of, than

filin tukar, jual: to exchange; to sell

fina wanita, betina: woman, female fina (war fina) tunangan perempuan: fiancee 
fina-fina gadis: girl, unmarried woman

finan sawan menantu perempuan: daughter-in-law

fingit nyamuk: mosquito

flahi memukul: to beat, to hit, to

strike

flale mengancam: to threaten

flauwe laut: sea, ocean

flehe memukul, tendang, tumbuk: to

beat, to strike; to kick; to pound

fofo bubu: basket-trap for fish

fogi (dafogi) membasahi: to wet

foi mandi: to take a bath

fola memutus, memotong: to cut; to

break off, to sever

foni sembunyi-sembunyi, diam-diam:

secretly

foto (1) dendam: vengence, grudge

foto $(\overline{2})$ mengiris, merajang: to slice, to cut in small pieces

foto (3) (dafoto) bakar: to burn

frani dekat, pendek: near, close

by; short in time, length, or height

frema jauh, panjang: far, distant;

long in time, length, or height

freng dengan: with; by means of

frenge dengar: to hear

frete ke sana: to there, yonder

fridi dingin: cold

fru' (dafru') menyala: to flare

up, to flame

fua pinang: areca

fuan buah pinan: areca nut

fuan (fahanan fuan, gegenan fuan)

pantat: buttocks

fuanan bahu: shoulder

fuat pisang: banana

fuatlahin (? fuan lahin) batang

kayu: log, piece of wood

fufan lalen wajah: face, visage

fuhanan perut: stomach

fuhenan tumit: heel

fuikun sikut: elbow

fuk berak: to defecate

fuka membuka: to open

fulan bulan: moon; month

fulan (dakita fulan) datang bulan:

menstruate

fulanan goa bulan terang: full

moon

fulon lubang: hole

fulon (hian fulon) lubang mayat:

grave, burial place fulun rambut: hair

fulun (raman fulun) idap, bulu

mata: eyelash

fusu bunga: flower, blossom

fut kentut: fart; to fart

futu membakar: to burn s.t.

gabus gabus: k.o. fish; cork

gae bintang: star

gagi bubu: basket-trap for fish

gagu gunung: mountain

gala (dagala) tersangkut: to get

caught, snagged

gama sanak, sama: relative; same;

equal; alike

gamda mengapa, bagaimana: why;

how, by what means

gamna begini: in this way; thus

gami begini (? begitu): in this

way; thus; (? in that way)

ganutu aren, enau: sugar-palm

ganemo melinjo: k.o. tree

gayawas (? goyawas) jambu klutuk:

guava

gea (damgea) malu-malu: shy,

bashful; coy

geba orang: person, human being

geba bolo' bujang: unmarried;

bachelor

geba doi bodoh: stupid,

unintelligent

gebanhekat pelarian: race;

racetrack; fugitive

geda (1) tua: old

geda (므) terkejut: startled, taken

aback

geda (2) (kageda) terkejut:

startled, taken aback

gefina perempuan, betina: woman, female

gege ribut: stir, cormotion; to

make a fuss

gegenan fifa ketiak: armpit

gegenan fuan pantat: buttocks

geger gemetar, gigil: to shiver;

to tremble

geha jatuh: to fall, to drop

gela goreng: fried; to fry

gelabah rusak: damaged, ruined; destroyed

gelan (niwaen gelan) minyak kayu

putih: cajuput oil

gelas gelas: glass, tumbler

gelen biru: blue

gema sama: same; equal; alike 
gera goyang: to rock, to shake

geren sisa, beda, lebih: left

over, remaining; remant; different;

more, extra

gesu patah: to snap, to break;

snapped, broken

giban orang: person, human being

gida (dagida) mega, awan: cloud

gidan luar: outer; outside

gido tegang: stiff, tense; taut

giha jatuh: to fall, to drop

giha (dagiha) telentang: to lie on

one's back

gili miring: aslant, askew, at an

angle

giwa sisi, tepi, seberang: edge,

rim; across, opposite

giwan separo: one half

glina (daglina) jernih: pure, clear

goali (dabgoali) hamil: pregnant

gogo (dagogo) halilintar: flash of

lightening; thunderbolt

gol tak berarti: insignificant,

without meaning

golo kurus: thin, skinny

golo' (dagolo') petir: thunderclap

gopi kempes: deflated, flat

gosa kuat, gagah: strong, sturdy;

brave and handsome

gosa (dagosa) baik, cantik, kuat,

gagah: good; beautiful, lovely;

strong; brave and handsome

gosa (fulanan gosa) bulan terang:

full moon

(? goyawas) gayawas jambu biji: guava

grorohi sumpah: oath, to swear

gufa gulung: a roll of something

gufut kura-kura: turtle

guhu mengubah: to change, to

alter; to transform

guling berputar: to rotate

habana di sinihere, in this place

habani di situ: there, in that

place

habeto kemarin: yesterday

habu maki: to abuse with words

hada menggigit: to bite

hadu aduk: to stir s.t.

hae sudah: already, past, over

with finished

hafa simpan: to store, to lay by; haga kira-kira: roughly, more or less; most likely

hagi meminjam: to borrow

haka (dahaka) ikal, keriting:

curly, wavy; crinkly

hakan sisir: camb; to comb

hala padi, beras: rice

halai ingat, pikir: to remember,

to bear in mind, to think, to

consider

halat hari, matahari: day; sun

halat kere siang: daytime; forenoon

halat pao sore: afternoon, early evening

halat rete pagi: morning

halowi menyimpan: to store, to lay

by, to save up

halui membersihkan: to clean; to purify

hama mencari: to seek, to look for

hama (damhama) ringan: light in

weight; easy

hangat hari, matahari, surya: day; sun

hangatori larmau, dulu: past; over with; previous; before

hangina sekarang: now, at this time

hanginana nanti: soon; later on

hangon dahan: tree branch

hanyur hanyut: carried away with current or tide

hapu ikat: band; to tie

harap harap: to hope; to expect

hau angkut: to carry, to transport

hawa ladang: unirrigatd cultivated field

hedi masih: yet, still

heka lari: to run; to escape

hela tarik nafas: to breath, to inhale

helanantapot melamun: to daydream

hele ingat: to remember, to

recall; to bear in mind

helu ikat: band; to tie

heset dinding, gaba-gaba: wall;

garland made of coconut leaves

hewang hutan: jungle, forest

hia harus: to have to, must

hian mayat: corpse

hian fulon lubang mayat: grave,

burial-place

hiba dada: chest, breast 
hidi untuk: for; to; in order to hidituba umum: general; camnon; public

himlau berilah: give (imperative)

himlese pesan: message; order, instruction

hiya harus: to have to, must

hobo cuci: to wash (clothes,

dishes, etc.)

honi (dahoni) memasak: to cook

hono susu: milk; udder, teat

hopi bersiul: to whistle

hori (1) menoleh, gerak-gerak: to

turn, to look around; movements

hori (2) (dahori) condong:

leaning, inclining

hosi jeruk: citrus fruit

huda bongkar: to break into, force open

huka bambu: bamboo

huka (uta huka) rebung: bamboo shoot

huke memberi: to give, to provide

huluk semua: all, every

huma (lale huma) kamar: room

humanewen cicak: house lizard

hunup tulang dada, tulang rusuk:

breastbone, rib

hunup tiap susu: milk; udder, teat

husan daun pisang kering: dried

banana leaves

i karena: because, because of

ibul pohon sudeng: k.o. tree

iga (daiga) minta: to ask, to

request

igu (daigu) manja: spoiled (of a

child)

ijina ijin: permission

ikabul ikan gabus: k.o. fish

ikalakat ikan betik: k.o.

freshwater fish

ikang ikan: fish

iko pergi, gerak: to go; to move,

to be in motion

iko li pulang, balik: to return

(home), to go back; to turn around

iko lili berkeliling: to go round,

to circle round s.t.

iko polo ikut: to follow; to join

in

ikun ekor: tail

ilang hilang: vanished, gone, lost

ina ibu: mother

inawet ular: snake ine tidur: to sleep

inpaet tikus: mouse, rat

inpait pahit: bitter

inu minum: to drink

inuk (meten inuk) mendung: cloudy, overcast

ipi tindik: to pierce

irit pisau: blade, knife

irosi (mester irosi) sangat

penting: very important

isa membungkus: to wrap up s.t.; to envelop

isai menguliti: to skin; to peel

isi memetik: to pick (flowers); to

pluck (musical instrument)

isin gigi: tooth

iso goyang, gerak: shaky; rocking; motion

iso (daiso) bergerak: to move, to

be in motion

ita jadi, maka: and so; thus; and

then

italeta jadi: and so; thus

itang hitam: black

ite lahin pohon pule: k.o. tree

iye samo tak apa-apa: no matter,

it doesn't matter

iyen barang: things, goods,

commodities

iyor barang: things, goods, comnodities

ka makan: to eat

ka' nual sunduk ikan: skewer for fish

kaba kabar, sebut: news,

information; mention

kabahara akar bahar: medicinal

seaweed

kabi (dakabi, daskabi) tebal:

thick, dense

kabih menyangkut: to involve

kabuki astaga, aduh: exclamation of annoyance or pain

kadakut belakang: back, rear;

behind

kadan kaki: foot

kadan lalen telapak kaki: sole of

the foot

kadan lipat bersila: to sit crosslegged

kadan tean betis: calf of leg

kadefu pohon bakung: k.o. shrub

kadremon katak: toad, frog

kadu datang: to come, to arrive 
kae kau: you

kaena karena: because, because of kafi dari: from, of; than

kafi do dari mana: where from kafi pao dari bawah: fram below, from underneath

kageda terkejut: startled, taken aback

kahik debu: dust

kai (1) kakak laki-laki: elder brother

kai (2) kau: you

kait larangan, tabu: a taboo, ban

kakahi nyiru: winnowing tray

kakai kakak laki-laki: elder brother

kakangisin kemaluan laki-laki:

penis; male genitalia

kakofak telungkup: face downward,

to lie face downward

kakong punggung: back (anat.)

kaku gunung: mountain

kalabasa (1) buah maja: fruit of

k.o. tree

kalabasa (2) gila: crazy, insane

kalah kalah: to be worsted

kalakat ikan betik: k.o. freshwater fish

kalamo kopi anjing: k.o. special coffee (?)

kalebal pikulan: carrying-pole, load

kali gali: to dig, to excavate

kali keranjang kecil: a small

basket

kaloti cubit: to pinch

kaluken kuskus: k.o. marsupial

kam kamu: you (familiar)

kamin kenari, pohon kenari: k.o. nut tree

kaminan kau punya: your, yours

kampung kampung: kampong, hamlet

kanasi nanas: pineapple

kangulun bantal: pillow

kanhilut sabuk: sash, waistband

kanital jembatan: bridge

kare pintu: door; gate

karumun daun: leaf

kasahal sapu lidi: broom made of palm leaf ribs

kasahal newe lidi: palm leaf ribs kasi (1) (wai kasi) mengalir: to flow

kasi (2) menggali: to dig, to dig up, to excavate

kasi (2) datefa (dakasi datefa)

cukil: to dig out, to gouge out, to pick

kastena lambok: red pepper

kataji jambu mete: k.o. fruit

katatehan celana: pants

kau kayu: wood, timber

kau kunut kayu waru: k.o. wood

kawa luka: wound; wounded

kawatir kawatir: to feel

apprehensive

kawil mengail: to fish with a hook

kawil ngisin mata kail: fish-hook

kawil nihin tali kail: line for fish-hook

kawini mangga gadung: k.o. mango

kaya (1) menggigit: to bite

kaya (2) kaya: rich

keba anak, menantu: child; son-in-

law; daughter-in-law

kebo tas tempat sirih: bag for

holding betel-chewing ingredients

keda tua: old, ancient

keda (dakeda) tua: old, ancient

keha naik: to go up; to ascend; to climb

kelabur sembarangan: anything,

anyone at random

kele (1) paha: thigh

kele (2) (damkele) tinggi: high,

tall

keleda sejenis burung: k.o. bird

kelen paha: thigh

kelet tinggi: high, tall

kelinganan telinga: ear

kene (dakene) tuli: deaf

kepeng uang: money

kere (1) berdiri: to stand

kere $(\overline{2})$ atas: above, top

kere () (halat kere, hangat kere)

siang: daytime; forenoon

keso patah, petik: to break; to

snap; to pick (flowers); to pluck

(musical instrument)

kete mertua: parent-in-law

kete (ama kete) mertua laki-laki:

father-in-law

keto bersetubuh: to have sexual intercourse

kewero mendirikan: to build, to erect

kimi kamu: you (familiar)

kiminan kamu punya: your, yours 
(familiar)

kimle (kolekimle) antar: take s.t. or s.o. somewhere, deliver

kintal batas: edge, limit

kira kira: to guess; to estimate; to have an opinion

kirarahi dahi: forehead

kiso mengkedip: to blink, to wink kita (dakita) datang: to come, to arrive

kita (dakita fulan) datang bulan:

menstruation

kita (niwaen kita) minyak kelapa: coconut oil

kleko tuhun (dakleko tuhun) jalan

belok: curve in a road, winding road

klope memukul: to beat, to hit, to strike

koani (damkoani) bagaimana: how,

by what means

kogiha jatuh: to fall, to drop

koit larangan, setan: a taboo,

ban, devil, evil spirit

koke (dakoke merangkak: to crawl

on all fours, to grovel

koko keranjang kecil: a small

basket

kolekimle antar: to bring s.o. or

s.t. somewhere

kolinhisin tai lalat: birthmark,

mole

komisi periksa: to inspect, to investigate

konde gelung: coil; hairknot, bum

kopek walesan kail: fishing rod

koren pintu: door, gate

koto kutu: louse, flea

kowai rusak: damaged, ruined; destroyed

kreat burung betet: k.o. parrot krei (dakrei) tak bisa: cannot, is unable to

kri (dakri) takut: fear; to fear

kua mengapa: why

kudu mengasah: to sharpen, to hone

kufut kubur: grave, burial-place

kuhili bebek: duck

kukat sampak kali, sangkrah:

barrier of sticks

kukili menggelitik: to tickle; to

prod; to incite

kule biji: seed, kernel, stone

kulen isi: contents kulun bawah, kolong: under; space under a house

kunit kuning: yellow

kunut (kau kunut) kayu waru: k.o.

wood

kusu semak: bush, shrub

la bila, kalau: if, when

labun baju: clothing; shirt,

blouse

lafut (uta lafut) bayam: spinach

laga laga, adu: animal fight, to

pit an animal against another

lagamal (tiput lagamal) jago: fighting cock

lagan seperti: as, like

laha untuk, hampir, pada: for, to, in order to; almost; at

lahi (1) (dalahi) sampai: to

reach, to attain; up to, until

lahi (2) (flahi) memukul: to beat, to hit, to strike

lahin pohon: tree

lai untuk, bagian, pada: for, to,

in order to; a part; at

laka galah: pole, punting-pole

lakah kupas: to peel; to string

lakan tanda: sign, mark

lakat duri: thorn

laken kupu-kupu: butterfly, moth

lale dalam: in; inside; deep

lale (aki lale) dalam kamar:

inside the room

lale huma kamar: room

lalen hati: liver, heart

lalen (aki lalen) dalam hati: in

the heart

lalen (fufan lalen) wajah: face,

visage

lalen (kadan lalen) telapak kaki:

sole of the foot

lalen (pupan lalen) wajah: face,

visage

lalen tuka cinta padamu: (I) love

you

lali (tuma lali) kutu busuk:

bedbug

lane sampai: to reach; to attain;

up to, until

langa (1) antara: between

langa $(\underline{\overline{2}})$ angkat: to lift, to lift

up

langgar lewat: to pass; through,

via

langit langit: sky 
langsa langsat: fruit of the dukutree

lapo' basah: wet, damp

larang melarang: to forbid; to ban lata membabat: to clear jungle

lata (dalata) membunuh: to kill

lau memijat: to squeeze; to massage

lauwe (1) sampai: to reach, to attain; up to, until

lauwe (2) (flauwe) laut: sea, ocean

lea warot (dalea warot) muat: to contain, to hold

leba memikul: to shoulder; to carry on the shoulders

lefa mengubur: to bury

lehe (flehe) memukul, tumbuk, hantam: to beat; to strike; to pound

leli balik, pulang, putar: to go

back; to go home; to turn

leo depan: front; in front, ahead

leso lesung: rice mortar

lestar destar: Javanese headcovering

letewang paha: thigh

leuk dulu: formerly, former; beforehand; for a mament

liak bicara, bahasa: to speak, to talk; language

liasit adu domba: to play s.o. off against another

liba (1) memukul: to beat, to hit, to strike

Iiba (2) bawa: to bring, to carry

libo (dalibo) keruh: turbid, muddy; disturbed

lidak boleh: permitted, may

liemgian bicara malu-malu: to speak shyly; to speak coyly

lien bicara, suara: to speak, to talk; voice

liet bunyi: sound, resonance

liha pisah, pindah: to part; separated; to move one's place

likat lain: other; different

liket lain: other; different liku curam, dalam: steep; deep

Iili keliling, putar: around; to circle, to rotate; to go round

lima lima: five

limar kikir: stingy; a file, a limatan denda: a fine

linga telinga: ear

lingak mengintip: to spy on, to peep at

lipat (kadan lipat) bersila: to sit cross-legged

liptot tanda arah: sign-post

loa membuat: to make, to do

loban akar: root

lofa' usir: to evict

logik menindas: to oppress, to suppress

lokni mulai, sejak: to begin; since, ever since

loli (1) gulung: a roll; to roll

loli () (daloli) tergelincir: to slip; to have slipped

luasanumum daun pisang kering:

dried banana leaves

lubi cacing: worm

lubuik (? lubu') kumpul, semua: to gather, to assemble, to collect; all, every

lubuk (dalubuk) bermaksud: to intend, to mean; to have the intention to

lubuk (saha lubuk) sapu kumpulkan: a broom to gather things together

luken pucuk, ujung: top, tip, apex, point

luputun panas: hot; heat

luru cari: to seek, to search for lutuk enthong: rice-ladle made of wood or coconut-shell

ma-an lidah: tongue

ma'ai membelai: to caress; to flatter

madi pohon keluwih: the seeded

breadfruit tree

magege terburu-buru: hastily

mahate memetik: to pick (flowers);

to pluck (musical instrument)

mahet bernafas: to breathe

mahi mari: come! let us...

mahilang malas: lazy

mahun obat: medicine

mako (damako) jinak: tame, gentle

mala kotor: dirty

mali tertawa: to laugh

maloa bekerja: to work

marnaca tak marmpu: not capable of

man lidah: tongue

$\overline{\text { mana }}$ orang laki-laki: man, a male mana bolo' bujang: unmarried, 
bachelor

mana (war mana) tunangan laki-laki: fiance manan sawan menantu laki-laki: sonin-law

mandawas pembohong: liar, cheat mangado mengganggu: to disturb, to

bother; to interrupt

manganei garmpang: gampang

mangat sangat: very

mangin dangkal: shallow

mangit kering: dry

mangkau (mangkao) kasbi: cassava

manika baru: new, recent; just

(now)

manu (wai manu, ? wai manuk) surut:

to ebb; ebb tide

manu tunit burung srigunting: k.o.

blackbird

manuk (1) turun: to go down, to

descend; to decrease

manuk (2) (wai manuk) surut: to

ebb; ebb tide

manut burung: bird

mao mau, suka: to like, to enjoy;

to like to do s.t.

mao (damao) berteriak: to yell, to

shout, to scream

mapiri bersih: clean

mapuk memasak: to cook

mara tunggu: to wait

mara-mara hati-hati: careful,

cautious

marafeni nanti: later on; in a

moment

marapo menjilat: to lick

mareru telan: to swallow; to

swallow up

marmale besar: big, large, great

marsego kalong: flying fox

marsego lahin pohon gempol: k.o.

tree

masa matang: ripe, mature

masam (1) masak: ripe, cooked; to

cook

masam (2) tua: old, ancient

masi membelai: to flatter

mata mati: dead

mata (damata) mati: dead

? matai (matei) panen: harvest

mate (uta mate) sayur daun-daun:

leafy vegetables

mate (uta mate) merambat: to

spread, to creep matei (? matai) panen: harvest

mawa menguap: to steam, to

vaporize; to yawn

medet hitam: black

medet (damedet) hitam: black

medihe bawalah: take it! take it

with you!

mei (damei) sesak, seret:

congested, blocked, tight, sluggish

mei-mei pelan-pelan: slowly

memaligues tertawa bersama-sama:

to laugh together

memang memang: indeed; of course; naturally

meme paman: uncle

memek keponakan: nephew, niece

mena lama: long in time; ancient

menah terang, jelas: clear; evident

menelak tengah: middle, center

mengege terburu-buru: hastily

meniket getah, pelikat: sap, gum;

glue

menima batuk-batuk: to have a

cough

mensa manusia: man, human being

menyao menyahut: to answer, to

reply

menyao bela bertanggung jawab: to

be responsible, to account for

mester perlu: need, to have to

mester irosi sangat penting: very important

meteba mengunyah: to chew

meten awan: cloud

meten inuk mendung: cloudy, overcast

meteri daerah: region, area

midi (1) mendukung: to support

midi $(\overline{2})$ (damidi, barmidi) gelap:

dark, obscure

midik mengajak: to invite

mifi (damifi) tipis: thin

mihat merah: red

mihat (wa mihat, ? wai mihat) darah:

blood

milhemo kumur: to rinse the mouth

milhemo (pamilhemo) kumur: to

rinse the mouth

mili (damili) sungguh-sungguh:

serious(ly), earnest(ly),

sincere (ly), wholehearted(ly)

minat panas: hot; heat

minat (daminat) teduh: calm, 
unruffled

minat (daminat) terang: clear,

bright

minhalen tempat tidur: bed

misa (damisa) manis: sweet

miti bersin: clean

miti (damiti) bersih: clean

mito (damito) kecut: sour;

shrivelled

mlapa lapar: hungry

mlese pesan: message; order,

instruction

mlisi menarik: to tug at s.t.; to

pull; to attract

mloko uling: k.o. eel of swamps

mo tidak, bukan: no, not

moa hutan: jungle, forest

modan sore: afternoon, early

evening

mofu' rambutan: rambutan, k.o.

fruit tree

mohe-mohe belum, tidak: not yet,

not

mohedi belum: not yet

moho jatuh: to fall, to drop

moho-moho tak senang:

discontented, not to like s.t.

molo (damolo) tenggelam: to sink,

to have sunk; to drown

momal besi: iron

mamol besi: iron

mopu' buah rambutan: rambutan,

k.o. fruit

morang pancung: cut off,

decapitate

mori suami: husband

moro gogo ikan: to catch fish with

one's hands

(?) msili bersih: clean, pure

mubat kaya germpol: k.o. tree

mudat kayu gempol: k.o. tree

mudut kadal: lizard

muehe cium: kiss; to kiss, to

sniff

muen mulut: mouth

mugea malu: shame; be ashamed

mumi cium: kiss; to kiss, to sniff

muram muda: young

musi-musi sungguh-sungguh:

serious (1y), sincere( $\left.l_{y}\right)$,

wholehearted ( $1 y$ )

mutan sayur: vegetables

muti sakit: sick, ill; sore, painful muti (damuti) sakit: sick, ill;

sore painful

mutum muda: young

mutun (niwe mutun) nyiur muda:

young coconut palm

na terus: straight; direct;

continual (ly)

na ini, di sini: this; here, in this place

na (nake) punya: to own

na (namo) punyamu: your, yours

na (nao) punyaku: my, mine

nabala itu dosa: that is a sin nado (fatu nado) batu asah:

whetstone

nafan tingkat: level, grade

naina kete ibu mertua: mother-inlaw

nak terang, jelas: clear, bright; evident

nakal nakal: naughty, mischievous nakan nangka: jackfruit

nakatalu tongkat: staff, cane, wand

nakatalu menyusu: to suckle an infant

nake punya: to own

nala (uba nala) sagu bubur: sago

porrige

namo punyamu: your, yours

nanaungan jari: finger, toe

nangan badan: body

nangan namanya: his (her, its)

name

nanggo menyeser: to fish with a

dragnet

nangun renang: to swim

nani milik: property

nao punyaku: my, mine

naoture separoh: one half

nasa saringan: sieve, strainer

nawa ijuk, tali: palm fiber, cord, string

ne enam: six

nehe cukup: enough, sufficient

nei menaruh: to bet, to stake; to

lay s.t. down

nekat bermaksud: to intend, to

mean, to have the intention of

nelak tengah: middle, center

nelet tali: cord, string

nepi mimpi: dream; to dream

nero tombak: spear

neroe hidup: alive; life 


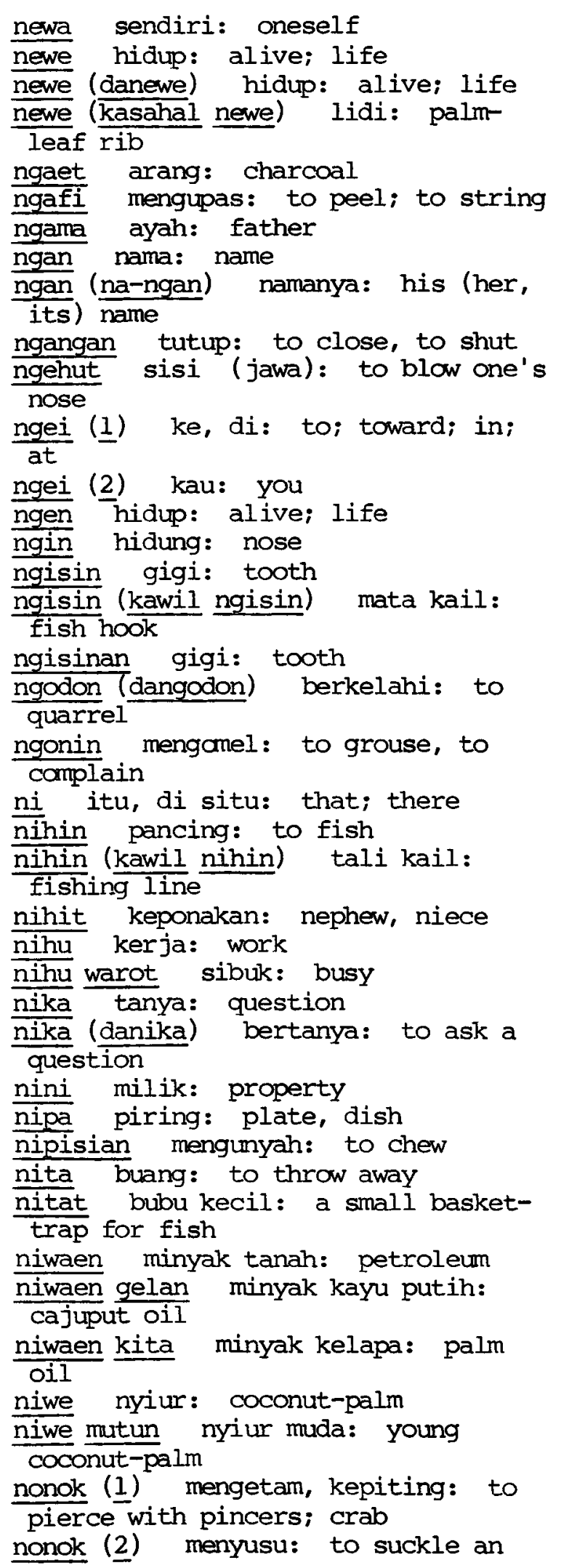


behind times

pandingi sabuk: sash, waistband panyara biar: to permit, to let go; even though

pao bawah (di bawah): underneath, below

pao (dapao) taruh di bawah: to place underneath, to place below pao (halat pao, hangat pao) sore:

afternoon, early evening

pao (kafi pao) dari bawah: from

beneath, from below

papai papaya: papaya

papan pipi: cheek

para (dapara) rendah: low; humble

paran pendek: short in time,

length, or height

pare sama: same, equal, alike

parkara perkara: matter, case

paso (dapaso) pecah: broken,

shattered

patanik tomat: tomato

patar pikir: to think, to have an opinion

patar gosa kira-kira baik: most

likely good

pato (I) dapat: to get, to obtain; to be capable of

pato (2) (dapato) panas: hot; heat

patut (1) harus: to have to, must

patut $(\overline{2})$ bubul ulcer on the foot

paute supaya: in order to

pe lagi, lalu, juga: again; and

then; further; also

pedet (dapedet) busuk: putrid; rotten

pehe injak: to trample on

pei sakit: sick, ill; sore, painful

pei (dapei) sakit: sick, ill;

sore, painful

pei (ulun pei) sakit kepala: to

have a headache

pele tutup: to close, to shut

pele jemput: to go to meet s.o.

pene dulu: formerly; beforehand;

for a mament

penek ngeden (jawa): to squeeze,

to press; to massage

pepai papaya: papaya

pepe (dapepe) menekan: to press

peren kawung: sugar-palm leaf

pesa (dapesa) menetaskan: to hatch eggs; to cause; to produce pese menegang: to hold on to s.t.: to clutch

pesetkehan, (? pesekehan) cekik:

to choke, to strangle

pesona menetas: to hatch eggs

pili perbaiki: to improve

pirimede gelap: dark, obscure

piringtuta piring seng: zinc plate

podi (dapodi) kenyang: satiated, full (of food)

poin (ubak poin) sagu iris: sliced

sago

poli kembalikan: to return s.t.

polo peluk: to embrace

polo ikut: to follow; to join in

poloh sepuluh: ten

posampoan jantung: heart (anat.)

potih putih: white

prakat becek: muddy, slippery

preko kumur: to rinse one's mouth

prigi sumur: a well

prusa isi peluru: gunpowder

prusi kepala pemuda: head of a

youth group

ptuha ludah: spittle

pu kentut: fart; to fart

puda timbul: to arise, to emerge

puha peras: to press, to squeeze

pupan muka: face; front

pupan lalen wajah: face, visage

pusin pusat: center; navel

rabo cepat: rapid, quick

raha layu: withered; weak, pale

rahan darah: blood

rahe tanah, bumi: earth, land

rahin tulang: bone

rahu bocor: to leak

rakat lengket: to stick, to adhere

rake (1) kotor: dirty, foul

rake $(\overline{2})$ nanti: later; in a mament

raki (daraki) kotor: dirty, foul

ramal (uta ramal) melinjo: k.o.

tree

raman mata: eye

raman beben alis: eyebrow

raman boho' buta: blind

raman fulun idap, bulu mata:

eyelash

raman wain airmata: tears

ramena lama-lama: in the long rum

range minta, mau, tanya: to ask

for; to want; to ask a question

rani (frani) dekat, pendek: near, close; short in time, length, or 
height

rapat (1) hampir: almost

rapat $(\overline{2})$ jejer: in a line

rarang ribu (seribu): one thousand

rasa rasa: feeling, sense of

feeling

raut kelelawar: k.o. small bat

rea rumput, lumut: grass; moss

rekeng (darekeng) menganggap,

menghitung: to regard, to consider, to estimate; to calculate, to count rema jauh, panjang: far, distant;

long in length and in time

rema (frema) jauh, panjang: far,

distant; long in length and in time

rema-rema setuju: agree with, be of one accord

remena muka (di muka): face;

front; in front of

reng (freng) dengan: with

renge (Erenge) dengar: to hear

repa depa: fathom

reru (dareru) menelan: to swallow

rese-rese benar-benar: truly,

really

rete di sana: there, yonder

rete (frete) ke sana: to there

rete (halat rete, hangat rete)

pagi: morning

retemena di muka: in front of

ridi (fridi) dingin: cold

rini dia: he, she

rogo masuk: to enter; to be

included in

rohi cari, selidiki: to seek; to

investigate

rohin (1) tulang: bone

rohin $(\underline{2})$ pendek: short in time,

length, or height

rosi sangat: very

rua dua: two

rupan rupa: shape, form,

appearance

rusa rusa: deer

sa menjerat: to snare

sabakopcara sombong: arrogant

sabi sabut: husk

sade menjawab: to answer

sadi menjawab: to answer

safe membeli: to buy

safe (dasafe) membeli: to buy

saha sapu: a broan to gather

together

saha lubuk sapu kumpulkan: a broam to clean with

saha yasi sapu bersih: to sweep clean

saki dari: from, of; than

sale terima: to receive, to accept

salepe menerima: to receive, to

accept

sali membelok, toleh: to turn

aside; to look back

salulu tali: cord, string

sama sama: same, equal, alike

samana sama dengan itu: the same

as that, like that

samaruka saringan besi: iron

sieve, iron strainer

samo (iye samo) tak apa-apa: no

matter, never mind

sane siapa: who

sanga menggigit: to bite

sangsara sengsara: suffering,

misery

sangues tertawa sama-sama: to

laugh together

sangusa tertawa sama-sama: to

laugh together

sansuba mengeluarkan: to take

outside

sapan apa: what

sapkoko cincin: a ring

saro sama-sama: equally; together

saru parut: rasp, file

sasa menggosok: to rub; to

burnish, to polish

sasat sesek: tight crowded,

suffocating

sasi garam: salt

sau menjahit: to sew

sauk becek: muddy and slippery

sawan menantu: son- (daughter-)

in-law

sawen bunga: flower, blossom

sayang sayang: pity; love

sebau menutup: to close, to shut;

to finish

sebiri buang: to throw away

sefe marah: anger; angry

segela (? sgela) goreng: fried; to fry

sehan parut: rasp, file

sehe mundur: to retreat, to

retire; to deteriorate

sei capai: tired; exhausted

seka menanam: to plant s.t.

sekabih terjepit: to be wedged, to 
be caught in pincers, be in a bind sekalasaro (? skolasaro) merangkul: to hug, to embrace sekope pecut: whip sele berenang, rendam: to swim; to soak

seleba selendang: shawl, stole selem lagi: again, in addition semake sembayang, berdoa: to pray semolat pesta orang mati: funeral celebration semolot pesta orang mati: funeral celebration

senang senang: pleased, happy; to like s.t.

(?) seni berat (see teni): heavy in weight

sensen kaca mata selam: goggles for diving

seo menutup: to close, to shut; to finish

sepa sepak: kick

sepo habis: finished; used up

sepsepo sama-sama: equally;

together

seroto mundur: to retire, to

deteriorate

seroto tubruk: to strike; collide

with

sesuk tenggelam: to sink; to drown

setia lepaskan: to let go, to

release

setufa terantuk: to be bumped, stubbed against

seu membayar: to pay; to pay for

sewu tutup: closed; to close

sida (dasida) panas: hot; heat

sigi bakar: to burn s.t.

sihon panu: k.o. skin disease

sika kucing: cat

sila mudik: upstream; to go

upstream

sili (emsili) bersih: clean

siluk senduk: spoon

sina bentang: to spread out

sini sisir: comb; to comb

sipa menikam: to stab, to pierce

sipat batas: limit, edge

sipen kemaluan perempuan: female genitalia

sisan kubur, kuburan, keranda:

grave, burial-place; lath frame to cover corpse on way to burial

sisela saringan: sieve, strainer sisin lebar: broad, wide

sisit semut: ant

sislale lupa: to forget, to overlook

sisuk perut: stamach

siu suruh: to command, to order

siwat jerawat: pimple, blackhead

siyan satu: one

skabi (daskabi) tebal: thick, dense

skena (daskena) rindu: yearning, homesickness; desire; to yearn for

(?) skolasaro merangkul: to hug, to embrace

smirat (1) (dasmirat) licin:

slippery

smirat (2) (dasmirat) kain: cloth, skirt

soa kepala kampung: village

headman

soa-soa biawak: a reptile similar to an iguana

sodi memukul: to beat, to hit, to strike

sofi mengupas: to peel

soga tali: cord, string

sohi besok, tunggu: tomorrow;

later; wait

soi (1) membuka to open

soi ()ㅡ mendayung to row, to

paddle

solasi kemangi: k.o. herb like

basil

soli dayung: oar, paddle

sopaicua (? sopacua) pasti:

certain, definite, exact

sopaya supaya: in order to

suba keluar: outside, to go

outside; to leave

subun muda: young

subut sumpah: oath, to swear

subutkehat mata kaki: ankle

sugit ayakan: sieve

suha tuang: to pour; to decant

suka suka: to like; to be happy;

to be content

sungit keranjang: basket

supa besok: tomorrow

supa-supa besok pagi-pagi: early

tomorrow morning

susah susah: trouble, grief, sorrow; difficult; difficulty susur mengantuk: to feel sleepy tabado mana: which; where 
tado mana: which; where

taga (1) melawat: to call on the family of a deceased person

taga (2) ikut: to follow, to join

in

tagal tentang, karena: about, in

regard to; because, because of

taha potong, tebang: to cut, to

sever; to fell trees

taji taji: metal spur for

fighting-cock

taki merebus: to boil

takiwaen merebus air: to boil

water

tako takut: fear; to fear

talalu terlalu: excessive; too

talu memanggil: to call, to summon

tamlago telanjang: naked, nude

tamo (datamo) sial: unlucky,

unfortunate

tana ada: to be, to exist

tangada menghadap: to face; to

present oneself before (to)

tanggufa (datanggufa) telungkup:

to face downward

tangi menangis: to weep

tanin bibit: seed, seedling

taor teman: friend

taoto ada: to be, to exist

taplahi taplak: tablecloth

tara mencabut: to pull out, to

pull up, to extract

tare (datare) tebang: to fell

trees

tarpaca terpaksa: to be forced, to

be compelled

tas tas: bag

tasi tali: cord, string

tate taruh, meletakkan: to lay

s.t. down

tau mengisi: to fill

taun penuh: full

te teh: tea

tea (daptea) berdiri: to stand

tea demdemi (daptea demdemi)

berdiri tegak: to stand erect tean (kadan tean) betis: calf of

leg

teblekat katak: toad, frog

tebu tebu: sugar cane

tefa cungkil: to dig out, to gouge out, to pick

tefa (dakasi datefa) cungkil: to

dig out, to gouge out, to pick tehon pangkal: base, beginning

tehu kejar: to pursue

tei kencing: urine; to urinate

tekel (datekel) hinggap: to perch

teko ceret: kettle

tekoang poci: bowl

tela merobek: to tear, to tear in pieces

teltela mondar-mandir: to go back and forth

teneate pakai sarung: to wear a sarong

teni (1) (? seni) berat: heavy in

weight

teni (2) enak (rasa): agreeable

(feeling); tasty

tesi burung tengkek: k.o. small

bird

teta cuci: to wash; to clean

tetale balai-balai: bamboo cot

tete kakek, cucu: grandfather; grandson

tewa tahu, kenal, mengerti: to

know, to be acquainted with s.o., to understand

tiam podi kenyang: satiated, full

(of food)

tiap (hunup tiap) susu: milk;

udder, teat

tibak mancing, lempar: to fish; to

cast, to throw

tifa gendang: drum

tifi menyembelih: to slaughter

tifo (datifo) terbang: to fly

tifu tebu: sugar cane

tilun bertelur: to lay eggs

tine melihat: to see

tiput ayam: chicken

tiput lagamal jago: fighting cock

titohi keranjang segi empat:

square basket

to untuk, karena: for, to, in

order to; because, because of

tobeh mendorong: to push, to prod

todo parang: machete

tofa (? tufa) tuang, siram: to

pour, to decant; to pour water on plants

tohar trisula: trident

toho turun: to go down; to descend

toma kuat: strong, sturdy

tomo bermain: to play

tomtomo main-main: to do s.t. in

fun, not seriously 
tonan kuah: sauce, gravy

tonga (datonga) menaruh di atas:

to place upon, to lay s.t. down upon

tongkaan tompang dagu: to be in a

reverie; sad

tonin lutut: knee

topo pukul: to beat, to hit, to strike

toro tinggal: to stay, to live; to

be left over, to remain

toram (1) tenang, diam-diam: calm,

quiet, quietly, secretly

torom (2) main: to play

toso tanduk: horn of an animal,

antler

tota bohong: lie, falsehood

tote (datote) lemah, lunak: soft,

suamissive, weak, gentle

trihi mencabut: to pull out, to

extract

triulun menjambak rambut: to pull

out hair

truah delapan: eight

tu (1) dengan: with

tu (ㅁ) untuk, karena: for, to, in

order to; because, because of

tua tua: old, ancient

tuak mencuri: to steal

tuak (daptuak) mencuri: to steal

tuat aren: sugar-palm

tuba membunyikan: to sound, to

cause to make a sound

tufa (tofa) tuang: to pour, to

decant

tufe jengkal: span (of hand)

tuha (1) dengan, pada: with; at,

tuha (2) (daptuha) ludah: spittle tuhun jalan: road, path; method,

way

tuka (lalen tuka) cinta padamu:

(I) love you

tukar tukar: to exchange

tuma lali kutu busuk: bedbug

tunit tumang, tungku: support for

a brazier, brazier

tupal beda: different; to differ

from

tura (1) paruh: beak; half

tura $(\underline{2})$ (datura) mematuk: to

peck, to bite

turen pendek: short in time,

length, or height

tuta bohong, menipu: lie, falsehood; to deceive, to cheat

tuteku menyambung: to continue; to

connect, to join

tutuk menjalankan: to make to go,

to make to work; to drive

uba buaya: crocodile

ubak (? uba) sagu: sago

ubak poin sagu iris: sliced sago

uba nala sagu bubur: sago porridge

uba sgela sagu goreng: fried sago

udu hanya, baru: only, merely;

just (now); new

ula (1) gila: crazy

ula (2) gelisah: anxious, apprehensive; nervous

ule (1) telat: late, overdue

ule (2) ulat: caterpillar, worm

uli pulang, balik: to return

(home), to go back

ulun kepala: head

ulun pei sakit kepala: to have a

headache

ulut pohon laosan: k.o. tree

umun daun: leaf

una (dauna) penuh: full, full of

untung untung: good fortune, luck;

profit

untut untuk: for, to, in order to

upsodi berkelahi: to fight with

fists, to quarrel

upuataala tuhan: God

uran udang: shrimo

urus mengurus: to arrange affairs,

to put in order

uta boti jamur meranti: k.o. edible fungus

uta huka rebung: bamboo shoot

uta lafut bayam: spinach

uta mate (1) sayur daun-daun:

leafy vegetables

uta mate (2) merambat: to spread;

to creep

uta ramal melinjo: k.o. tree

utan sayur: vegetables

ute sumbu: fuse, wick

utun seratus: one hundred

utut lumpur: mud

uwa rotan: rattan

wa mihat (? wai mihat) darah:

blood

wadara, wadare terjun: to jump

down, to dive

wadun leher: neck

waet basah: wet, darmp 


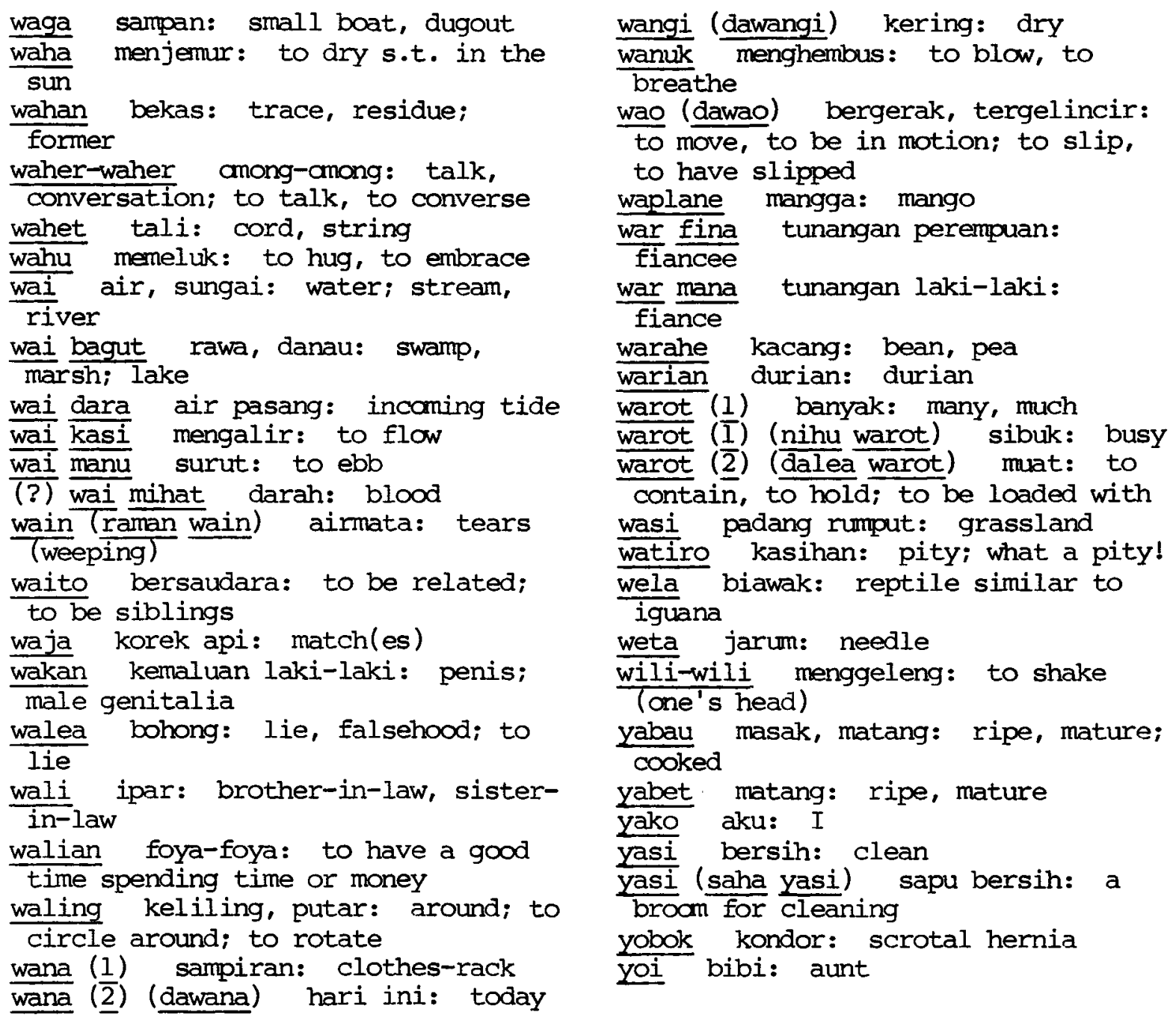

